УДК $82.091+821.161 .1$

DOI: $10.17223 / 24099554 / 12 / 6$

\title{
Е.Ю. Сафронова
}

\section{ОБРАЗ ГЕРМАНИИ В СИБИРСКИХ ПРОИЗВЕДЕНИЯХ Ф.М. ДОСТОЕВСКОГО}

В статье рассматривается, как в сибирских произведениях Ф.М. Достоевского создается емкий, многогранный образ Германии. Писатель преклоняется перед иентром европейской ичивилизаичи (литература, философия, музыка, образование, техника), названы знаковые фигуры немецкой культуры (Кант, Бетховен и др.), обозначены топосы (Франкфурт, Карлсруэ), в произведениях используются немеикие выражения. Однако бездумное копирование, увлечение европейским грозит России утратой национальной самобытности.

Ключевые слова: Достоевский, Германия, Сибирь, топос, образ, немеч, "Дядюшкин сон», "Село Степанчиково и его обитатели», поэтика, комическое.

Тема взаимосвязи Достоевского и Германии широка и многоаспектна, но недостаточно изучена. Наиболее исследован биографический аспект, связанный с путешествиями писателя в Европу в 1862 , 1863, 1865, 1867 и 1879 гг. (А.С. Долинин [1], С.В. Белов [2], К. Hielscher [3] и др.). Другой, не менее интересный, - немецкая литература и философия как один из источников творчества Достоевского. Так, ученых особенно интересовало влияние Ф. Шиллера (Н. Вильмонт [4], Ю. Данилевский [5. С. 464-490], Kim R. Humiston [6], C. Schulz [7], И.И. Евлампиев [8] и др.), Г. Гейне (В. Комарович [9]), И.В. Гете (Г.К. Щенников [10], И.З. Серман [11], А. Ковач [12], Э.М. Жилякова [13]), И. Канта (Я.Э. Голосовкер [14], О. Осмоловский [15]), Ф. Шеллинга (В.Н. Белопольский [16] и др.), И. Фихте (И.И. Евлампиев [8]) на формирование индивидуальности и нарративных стратегий русского писателя. Много исследователей изучают и обратное влияние: метатекста Достоевского на развитие немецкой литературы, философии, культуры в целом (В.В. Дудкин [17], К.М. Азадовский [18], О.А Богданова [19], Н.-J. Gerigk [20, 21] и др.). Интегри- 
рующую функцию в этом направлении исследований выполняет Немецкое общество Достоевского. Так, например, цель конференции в 2009 г. в Католической академии имени Франца Хитце Хауса в Мюнстере состояла в том, чтобы проследить многочисленные связи писателя с европейской интеллектуальной историей, «оживить» его путешествия по Западной Европе, представить его письма и журналистику об европейском настоящем, осмыслить предлагаемую Достоевским антропологическую, географическую и, прежде всего, духовную перспективу ${ }^{1}$.

Кроме того, продуктивными являются имагологические исследования, созданные в междисциплинарном диалоге, на стыке истории, социологии, культурологии, географии, литературоведения, сравнительно-исторического языкознания, философии культуры.

В таком геокультурном, геопоэтическом аспекте особенно интересным представляется именно немецкая тема русской литературы. Во-первых, Россия со времен Петра I получила «прививку» немецкой культуры. Из Германии прибыло большое количество мигрантов, в основном представители интеллектуальной и культурной элиты (наука, медицина, образование, театр). По словам С.В. Оболенской, «ни с одним из европейских народов русские не имели, начиная с XVIII века, такого тесного и даже отчасти “домашнего” соприкосновения, как с немцами» [23. С. 10]. Во-вторых, А.Б. Криницын справедливо акцентирует родство русского и немецкого менталитетов, особую геополитическую близость, типологическое сходство культурного развития, культурную гомогенность России и Германии [24. С. 178-179]. В-третьих, в России в XIX в. наблюдается рост национального самосознания, осмысления места страны в мировой истории. Соответственно «многочисленные и разнообразные контакты русских с немцами не могли не войти в качестве сущностного компонента в реальность художественных произведений. Со временем образовался более или менее устойчивый комплекс неких сте-

${ }^{1}$ «Diese Tagung sollte Fëdor Dostoevskijs unterschiedlichen Beziehungen zur europäischen Geistesgeschichte aufdecken, seine Reisen durch Westeuropa aufleben und seine Briefe und Publizistik über die europäische Gegenwart vorstellen. Europa sollte eine anthropologische, geographische und vor allem eine geistige Perspektivisierung erhalten» [22. C. 7]. 
реотипных черт, маркируемых конвенциональной литературной “немецкостью”» [25. С. 126]. Так, уже в романтической литературе образ немца - зачастую бытовой типаж, «идеальный» филистер, квинтэссенция мещанской пошлости: «расчетливость, переходящая в скупость, аккуратность, переливающаяся в педантизм» [23. С. 42].

Как справедливо отмечает Н.В. Буткова, посвятившая диссертацию сравнению образов Германии и немцев в творчестве И.С. Тургенева и Ф.М. Достоевского, немецкие персонажи возникают «уже в ранних произведениях Достоевского («Бедные люди», «Двойник», «Записки из Мертвого дома», «Униженные и оскорбленные»). В основном это эпизодические персонажи, нередко данные в комедийном ключе. Писатель как бы продолжает гоголевскую галерею петербургских немцев» [26. С. 15]. Для такой сатирической традиции характерно пародирование путем снижения и гиперболизации черт характера инородцев: немецкая точность, расчетливость, педантизм, планирование за полгода, сентиментальность и т.д.

Есть исследования, посвященные изучению образа Германии в отдельных текстах Достоевского. Н.В. Буткова в своей диссертации [26] в основном касается больших романов писателя: «Униженные и оскорбленные», «Идиот», «Бесы», «Подросток», «Братья Карамазовы».

Р. Кидера рассматривает образы немцев и проявления немецкой культуры в романе «Преступление и наказание», вскользь затрагивая и другие произведения: «Зимние заметки о летних впечатлениях», роман «Игрок». Анализируя жизнь немецких эмигрантов в столице и немецкие артефакты в текстах Достоевского, она приходит к выводу, что «Петербург находился под влиянием немецкой культуры, а жизнь простых горожан было наполнено немецкими вещами» [27. С. 39] и Достоевский достоверно воссоздает эту особенность многонационального мира Петербурга.

Образ Германии в «Дневнике писателя» Ф. Достоевского рассматривали П.В. Алексеев и Э. Биллиет [28].

Всесторонне исследована тема Германии в повести «Двойник» (В.П. Владимирцев, Н.В. Константинова). Произведение отличается «художественным совершенством в разработке (раскручивании) немецкой темы в творчестве Достоевского» [29. С. 176]. Н.В. Константинова уделяет особое внимание интерпретации имен героев немецкого происхождения, описанию их функции в сюжете, делает вывод о диалогиче- 
ском строении сознания Голядкина, акцентирует связь героя с традицией народного кукольного театра (театра Петрушки).

В процессе подготовки «Словаря языка Достоевского» анализируя реалии культуры, истории и быта Германии, Р. Чаппл приходит к выводу, что интерес писателя к немецкой культуре «прослеживается с первых до последних произведений, начиная с «Бедных людей» и кончая «Братьями Карамазовыми», однако «в разные годы его интересуют неодинаковые ее тенденции» [30. С. 254]. В подтверждение своей точки зрения, ученый приводит следующую частотную таблицу [30. С. 254]:

\begin{tabular}{l|c|c}
\hline \multicolumn{1}{c|}{ Произведение } & $\begin{array}{c}\text { Дата } \\
\text { издания }\end{array}$ & $\begin{array}{c}\text { Число } \\
\text { ссылок }\end{array}$ \\
\hline $\begin{array}{l}\text { «Бедные люди» } \\
\text { «Белые ночи» }\end{array}$ & 1846 & 1 \\
«Чужая жена и муж под кроватью» & 1848 & 3 \\
«Маленький герой» & 1848 & 1 \\
«Дядюшкин сон» & 1857 & 2 \\
«Униженные и оскорбленные» & 1859 & 3 \\
«Записки из подполья» & 1861 & 12 \\
«Преступление и наказание» & 1864 & 1 \\
«Игрок» & 1866 & 4 \\
«Идиот» муж» & 1866 & 1 \\
«Вечный муж» & 1868 & 5 \\
«Бесы» & 1870 & 2 \\
«Подросток» & $1871-1872$ & 8 \\
«Кроткая» & 1875 & 5 \\
«Братья Карамазовы» & 1876 & 18
\end{tabular}

Комментируя данные, Р. Чаппл пишет: «12 из 22 упоминаний немецких реалий найдены в одном произведении - «Униженные и оскорбленные», где значительная часть фабульной истории героев развертывается в Западной Европе. Можно с достоверностью утверждать, что интерес Достоевского к немецкой культуре зрел одновременно с его творчеством в целом. Наибольший интерес вызывали у Достоевского три писателя: Гете, Шиллер и Гейне. Из 75 отсылок к произведениям немецких писателей в различных сочинениях его, принятых во внимание в приведенной таблице, 41 относится к этим трем писателям: 19 отсылок к имени и сочинениям Шиллера, $15-$ к произведениям Гете, 7 - к стихотворениям Гейне. Причем в «Братьях Карамазовых» отмечается больше ссылок на явления немецкой культуры, чем в любом другом произведении. 15 из 18 отсылок относятся здесь к трем названным писателям, 11 - к Шиллеру» [30. С. 254]. 
Недостаточно изученными видятся сибирские произведения писателя. Темы образов Германии касался М. Гиголашвили и вскользь Р. Чаппл, хотя она нуждается в более тщательном и подробной анализе. На наш взгляд, рецепция немецкой культуры в творчестве Ф.М. Достоевского до его посещения Германии (первый раз в 1862 г.) представляется наиболее интересной, поскольку позволяет осмыслить, как в художественном творчестве создается мифологема немецкой культуры, основанная не на индивидуальном опыте личности, а базирующаяся на стереотипных клишированных представлениях о стране и литературных претекстах.

Тема статьи логично вытекает из биографического контекста. Первое письмо Достоевского, адресованное брату Михаилу 30 января - 22 февраля 1854 г. из Омска, рассказывает о пережитом, но и также выражает стремление скорого возвращения в литературу. Пунктирно намечая творческие планы, автор просит прислать свежих литературных журналов («Отечественные записки»), историков древних, экономистов и отцов церкви. Понимая, что его запросы большие, конкретизирует просьбу: «Знай только, что самая первая книга, которая мне нужна, - это немецкий лексикон» [31. Т. 28-1. С. 172]. И далее: «Не забудь меня книгами, любезный друг <..> Пришли мне Коран. „Critique de rason pure“ Канта и <..> пришли непременно Гегеля, в особенности Гегелеву «Историю философии». С этим вся моя будущность соединена!» [31. Т. 28-1. С. 173]. T.e. Германия, немецкий язык и философия воспринимались автором как основание, предпосылки и источники творчества.

В сибирских произведениях Достоевского образы Германии и немецкой культуры представлены неоднозначно, амбивалентно. С одной стороны, Германия - сердце Европы, сокровищница высших достижений науки, образования, философии, искусства, популярное место стажировок, повышения квалификации, особенно в области инженерных наук, кораблестроения, медицины и т.д. Связи Германии с Россией были тесными и продолжительными, большое количество немцев привез Петр I и миграция продолжалась в XVIII-XIX веках.

Благодаря частым научным и культурным связям, Германии казалась близкой, почти родной, вследствие чего ее образ с легкостью подвергался комическому снижению и обыгрыванию. В литературе к обра- 
зу Германии обращался А.С. Пушкин и Н.В. Гоголь. Эту традицию сатирического снижения и осмеяния продолжает и Достоевский.

Важно отметить, что в повести «Дядюшкин сон» и романе «Село Степанчиково и его обитатели», восходящим к единому замыслу комического романа [31. Т. 2. С. 510], воспроизводится не реальный топос, а создается мифологема Германии. Так, например, сатирически обыгрываются небольшие размеры Германии по сравнению с огромной территорией Российской империи. Как остроумно замечает П.А. Мозгляков, у кучера князя К. Феофила «...борода с немецкое государство» [31. Т. 2. С. 318]. В этом ироничном сравнении очевидна разница масштабов стран по географической площади. В этой шутке сосредоточен сарказм автора: как при такой очевидной разности масштабов стран Россия может слепо, бездумно подражать модным тенденциям времени, иногда прямо противоречащим здравому смыслу. Например, князь К., выписал из-за границы «...бороду кучерскую, - действительно, борода заглядение! Но оказывается, что у Феофила своя собственная чуть не в два раза больше. Разумеется, возникло недоумение: сбрить ли свою или присланную назад отослать, а носить натуральную? Я думал-думал и решил, что уж лучше носить искусственную» [31. Т. 2. С. 318]. Тема бороды как знака «русскости» продолжена в реплике Москалевой о купце Бородуеве: «Я и всегда, впрочем, любила в нем всё это старинное русское, неподдельное...» [31. Т. 2. С. 339], а также авторском акцентировании облика князя К., который «...носил парик, усы, бакенбарды и даже эспаньолку - всё, до последнего волоска, накладное и великолепного черного цвета» [31. Т. 2. С. 300].

Протест против господского произвола кучером с говорящим

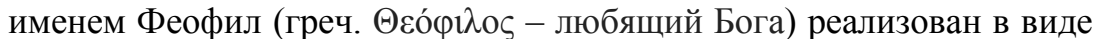
индивидуальной революции - перевернутой коляски с господином, что отменяет путешествие. При этом сам князь в дорожной «случайности» видит попытку покушения на убийство, позднее, вслед за Мозгляковым оценивает происшествие как анекдот. Петр Александрович, стремясь поразить слушателей в салоне Марьи Александровны своей образованностью называет случай спасения князя по дороге в Мордасов по-немецки: «Вот и вся история! Eine allerliebste 
Geschichte!» [31. T. 2. С. 306], что можно перевести как премилая или прелестная история ${ }^{2}$.

Использование немецкого выражения в щекотливой ситуации демонстрирует не столько способность Мозглякова с юмором отнестись к неприятной ситуации или гуманность героя, который всегда

${ }^{2}$ Отметим, что похожее выражение встречается и в повести «Крокодил», но с использованием траслитерации, в кириллице - «о мейн аллерлибстер Карльхен!» [31. Т. 5. С. 183]. В ППС это выражение (нем. O mein allerliebster Karlchen!) переводится как «мой милейший Карльхен» [31. Т. 5. С. 394]. На наш взгляд, более точно на русский язык это можно передать как «о мой дорогой или самый любимый Карлуша!», поскольку суффикс - chen имеет уменьшительноласкательное значение (Сp. Гретхен от Маргаретта, Грета в поэме Гете «Фауст»). При этом важно, что у обоих героев (Мозгляков и немец) «приступ» нежности появляется в момент возможной потери. Фраза в контексте обретает дополнительные смыслы: «О мой крокодил, о мейн аллерлибстер Карльхен! Муттер, мутер, мутер!» [31. Т. 5. С. 183], что переводится как «О мой крокодил, о мой самый любимый Карлуша! Матушка! Матушка! Матушка», отсылая в фольклорной немецкой песенке «Ach, du lieber Augustin»:

O, du lieber Augustin, Augustin, Ох, милый Августин, Августин, Augustin, Августин,

$\mathrm{O}$, du lieber Augustin, alles ist hin. Ox, милый Августин, всё пропало. Geld ist weg, s' Mäd'1 ist weg, Нет ни денег, ни девушек, Alles weg, Augustin. Bcë прошло, Августин.

$\mathrm{O}$, du $\mathrm{du}$ Augustin, $\mathrm{Ox}, \quad$ милый Августин, Alles ist hin. $\quad$ Всё пропало.

$<\ldots>\quad<\ldots>$

Jeder Tag war ein Fest, Каждый день был праздник, Und was jetzt? Pest, die Pest! A теперь? Чума, чума! Nur ein groß' Leichenfest, Только большой праздник мёртвых, Das ist der Rest. Это конец.

Augustin,

Augustin, Августин,

Августин, Leg' nur ins Grab dich hin! Ложись в могилу! $\mathrm{Oh}, \mathrm{du}$ lieber Augustin, Ox, милый Августин, Alles ist hin! Всё пропало!

Слова этой фольклорной песенки «Ach, du lieber Augustin», по наблюдению Р. Чаппла, также цитируются в оригинале («Mein lieber Augustin»), и в русской транслитерации («О мейн либер Августин») в романе «Униженные и оскорбленные» с целью осмеяния Генриха [30. С. 243]. 
готов прийти на помощь, а скорее показывает, что столичный франт твердо знает по-немецки лишь несколько фраз.

Германия представлена в повести «Дядюшкин сон» не только как законодательница мод. Достоевским иронически обыграны высокие стандарты немецкого образования, которое до сих пор считается лучшим в мире. В XVIII-XIX вв. оно пользовалось большим успехом среди русской дворянской молодежи, обучение было массовым и похожим на паломничество. С иронией об этом обстоятельстве биографии Ленского писал А.С. Пушкин в романе «Евгений Онегин»:

В свою деревню в ту же пору

Помещик новый прискакал

И столь же строгому разбору

В соседстве повод подавал:

По имени Владимир Ленской, С душою прямо геттингенской,

Красавец, в полном цвете лет,

Поклонник Канта и поэт.

Он из Германии туманной

Привез учености плоды:

Вольнолюбивые мечты,

Дух пылкий и довольно странный,

Всегда восторженную речь

И кудри черные до плеч [32. С. 68-69].

Геттингенский университет имени Георга Августа, который окончил пушкинский герой, славится классическим гуманитарным образованием, духом свободы. Однако воспитанные в Alma Mater высокие идеалы Ленского становятся плодом сплетен провинциальных помещиков и являются, в какой-то мере, и причиной гибели влюбленного поэта.

Продолжая литературную традицию, Достоевский очень иронично относится к классическому немецкому образованию и достижениям философии, воплотившей цвет немецкой культуры. Так, престарелый князь К. вспоминает о молодости за границей: «Я и философии обучался в Германии, весь курс прошел, но только тогда же все совершенно забыл» [31. Т. 2. С. 315]. Уточним, что во время молодости героя - начале XIX века - преподавали, к примеру, Г. Гегель, А. Шопенгауэр, И.К. Розенкранц, А. Тренделенбург, Ф. Шеллинг, Ф. Шлейермахер. 
Еще одним объектом пародии писателя становится основоположник немецкой классической философии, преподававший в Кёнигсбергском университете в 1755-1795 гг. Иммануил Кант. Фундаментальность и неприменимость к жизни немецкого классического образования саркастически высмеивается через сопоставление философа с образом слуги Тирентия, который «Глуп фе-но-менально! смотрит, как баран на воду! Но какая са-но-витость, какая торжественность! Кадык такой, светло-розовый! Ну, а - ведь это в белом галстухе и во всем параде составляет эффект. Я душевно его полюбил. Иной раз смотрю на него и засматриваюсь: решительно диссертацию сочиняет, - такой важный вид! одним словом, настоящий немецкий философ Кант или, еще вернее, откормленный жирный индюк» [31. Т. 2. С. 313].

Бесспорно, что изображение Терентия имеет карикатурный характер. По одной этой фразе можно сделать выводы о степени воспитанности князя и уровне его остаточных знаний. Поразительна способность героя сопоставлять, точнее, хаотично объединять, казалось бы, абсолютно несопоставимые вещи. В то же время, комическое сопоставление Достоевского, кажущееся на первый взгляд нелепым, имеет под собой глубокие основания и демонстрирует «глубину» сарказма, доходящего до гротеска. Кроме того, рискнем предположить, что Достоевский обыгрывает и некоторые любопытные подробности бытовой жизни философа.

Во-первых, И. Кант - основатель немецкой классической философии, преподаватель логики и метафизики, автор фундаментальных работ по гносеологии, этике и эстетике: «Критика чистого разума», «Критика практического разума», «Критика способности суждения», «Единственно возможное основание для доказательства бытия Бога», «Основы метафизики нравственности». Ему принадлежат философские категории категорического императива, трансцедентального идеализма, трансцедентального единства апперцепции, способности суждения, вечного мира. При условии, что князю К. около восьмидесяти лет, он теоретически мог быть учеником Канта:

«- Скажите, дядюшка, вы учились логике? < ..>

- Учился, друг мой, но только очень давно. Я и философии обучался в Германии, весь курс прошел, но только тогда же все совершенно забыл» [31. Т. 2. С. 315]. 
Во-вторых, у Канта есть трактат «Религия в пределах только разума», в котором идет речь о вариативности соотношения в человеке природно-биологического и когнитивно-социального. Другими словами, масштаб личности человека определяется его способностью духовного роста и доминированием одного из трех уровней.

«1. Задатки животности человека как живого существа.

2. Задатки человечности его как существа живого и вместе с тем разумного.

3. Задатки его личности как существа разумного и вместе с тем способного отвечать за свои поступки» [33. С. 96].

Сатирическое снижение и обыгрывание этой философской идеи Канта происходит в романе «Житейские воззрения кота Мурра» Э.Т.А. Гофмана, который также жил в Кенисберге и был учеником И. Канта, что подробно исследовал Л.А. Калинников [34-36]. Возможно, что и Достоевский проявляет интерес к этой книге философа. С другой стороны, в сопоставлении величайшего философа с индюком «просвечивают» некоторые интересные подробности бытовой жизни Канта.

Известно, что Кант не обладал красивой внешностью, был низкого роста, имел низкие плечи и впалую грудь. В его доме всегда было прохладно - не более 15 градусов, потому что он считал необходимым держать голову и ноги в холоде для сохранения здоровья.

В-третьих, Кант всегда был обаятелен и элегантно одет. В молодости у него даже было прозвище «элегантный магистр». Он исправно посещал портного и парикмахера, с тщательностью и педантичностью относился к мельчайшим деталям своего туалета. Однажды он даже потерял мысль и логику лекции, когда увидел беспорядок костюма его студента. «Кант имел обыкновение во все время лекции устремлять взор на одного из студентов, сидевших на передней скамье. Однажды случилось так, что Кант избрал студента, у которого не хватало на сюртуке пуговицы. Этот пробел в костюме молодого человека до такой степени нарушил покой Канта, что он был крайне рассеян, сбивался и прочел совсем неудачную лекцию» [37].

Пожалуй, самым юмористическим фактом в бытовой жизни Канта является то, что выдающийся философ был редким гурманом, превращающим еду в культ. Кант никогда не обедал в одиночестве, а был гостеприимным хозяином. Он считал, что число сотрапезников 
должно быть от трех до шести, чтобы беседа была приятной и всеобщей. Он далеко не был занудой даже в аудитории: он читал лекции медленно, разбавляя свои философские идеи юмором. «Знакомый с Кантом по работам и лекциям, - утверждает Яхман, - знает его лишь наполовину: полностью мудрец раскрывался в кругу собеседников» [38]. Застольный разговор превращался в игру, в которой нельзя допускать тягости тишины. За столом также важны умение поддержать беседу со всеми на любую тему, владеть аудиторией, выслушивать собеседника, примирять дебаты шуткой. Такова «эстетика разговора» [38].

Философ, одержимый идеей здорового образа жизни, позволял себе только одну трапезу в день. Обед был достаточно обильным, с хорошим вином и продолжался с 13.00 до 15.30. «Он ел не просто с аппетитом, но с наслаждением, - вспоминал один из гостей Канта (вероятно, не подозревавший, что у хозяина сутки до этого во рту не было ни крошки). На его лице читалось вожделение; выразительные взгляды, которые он бросал то на одно блюдо, то на другое, говорили о том, что в этот момент он целиком человек застолья» [38]. Кант действительно любил вкусно поесть, понимал толк в приготовлении пищи и был не прочь порассуждать на эту тему. Хиппель уверял, что Кант намеревался написать «Критику кулинарного искусства» [38].

Можно предположить, что Достоевский создает едкую пародию не только на личность, но и на философское учение Канта, соединяя и переворачивая в комическом образе кантианскую концепцию ступеней развития человека. Высшая ступень развития индивидуума это существо разумное и вместе с тем способное отвечать за свои поступки. Это сам великий немецкий философ Кант с его категорическим императивом. Вторая ступень развития индивидуума - задатки человечности его как существа живого и вместе с тем разумного - представлена в образе Тирентия, который «Глуп фе-номенально! смотрит, как баран на воду! Но какая са-но-витость, какая торжественность! Кадык такой, светло-розовый! Ну, а - ведь это в белом галстухе и во всем параде составляет эффект. Я душевно его полюбил. Иной раз смотрю на него и засматриваюсь: решительно диссертацию сочиняет...» [31. Т. 2. С. 313]. Низшая ступень развития индивидуума - это задатки животности, доминирование в чело- 
веке природно-биологического - «...такой важный вид! <..> откормленный жирный индюк» [31. Т. 2. С. 313]. Приемы нисходящей градации и оксюморона создают мощный пародийный эффект, низводя создателя немецкой идеалистической философии, автора категории чистого разума до жирного индюка.

Отметим, что индюк (Meleagris gallopavo Linnaeus) производит впечатление важной, самодостаточной птицы, которая с чувством собственного достоинства осуществляет незамысловатую деятельность. Первоначальное название - индейский петух. У индюка всегда шея и ноги красного цвета и сама птица имеет нарядный вид. В отличие от других пернатых индюк хорошо переносит холод.

Кроме того, в русском языке есть пословица «надулся как индюк (индейский петух)», которую используют по отношению к заносчивому, надменному, гордому человеку, имеющему напыщенный и глупый вид. Выражение имеет помету разговорно-сниженное и бранное. Словарь Даля фиксирует и выражение «думает как индейский петух» [39. С. 45]. То, что князь намекает на такие выражения в светском обществе, стремясь произвести впечатление на дам искрометностью юмора, напротив, обнажает изъяны его образования и манер. Кроме того, он использует разговорно-сниженные или диалектные формы слов: галстух, бакены, мамзель и т.д. В то же время по контрасту имя слуги Терентия происходит от лат. teres - вежливый.

Возможно, что к биографии Канта ${ }^{3}$, точнее его одиночеству, восходит следующий эпизод повести: «Я помню, когда я был за грани-

\footnotetext{
${ }^{3}$ Кроме того, с ориентацией и в полемике с И. Кантом будет разворачиваться дальнейшая художественная и публицистическая рефлексия Ф.М. Достоевского Важно, что имя философа возникает и в «Дневнике писателя». Так, в «Дневнике писателя» за август 1880 г. изображается картинка идеального общества - совершенного христианства, где каждый занимается тем, в чем имеет способности: «Представьте, что в будущем обществе есть Кеплер, Кант и Шекспир: они работают великую работу для всех, и все сознают и чтут их. Но некогда Шекспиру отрываться от работы, убирать около себя, вычищать комнату, выносить ненужное. И поверьте, непременно придет к нему служить другой гражданин, сам пожелает, волей своей придет и будет выносить у Шекспира ненужное» [31. Т. 26. С. 163]. При этом важно, что среди гениев духа, за которых добровольно выполняют физическую работу другие, чтобы освободить их часы, называется И. Кант. В «Дневнике писателя» за январь 1881 г. Достоевский вновь
} 
цей в двадцатых годах, там было у-ди-ви-тельно весело. Я чуть-чуть не женился на одной виконтессе, француженке. Я тогда был чрезвычайно влюблен и хотел посвятить ей всю свою жизнь. Но, впрочем, женился не я, а другой. И какой странный случай: отлучился всего на два часа, а другой и восторжествовал, один немецкий барон» [31. Т. 2. С. 315]. Кант был поклонником женской красоты. «Мыслителю нравились женщины, и он дважды хотел жениться. Но это был такой человек, который тщательно обдумывает важные решения. И оба раза Кант так долго думал над женитьбой, что первая невеста успела выйти замуж за другого, а вторая - переехать» [40]. В данном случае пародируется процесс быстроты / долготы обдумывания в принятии решения о заключении брака.

Кроме того, отметим, что «[в] глубокой старости Кант ослеп на левый глаз, но сохранил способность наслаждаться женской красотой: на застольях он предлагал красивым девушкам занять место справа от себя» [41]. Так и старый князь К. невзирая на возраст, является большим поклонником женщин.

Утрата Кантом в старости не только зрения, но и слуха сближает его с еще одним выдающимся представителем немецкой культуры Бетховеном, который тоже появляется в повести в речи старого князя К. в процессе хвастливого самоутвержения:

«Я очень люблю му-зы-ку. Я за границей с Бетховеном был знаком.

- С Бетховеном! Вообрази, Зина, князь был знаком с Бетховеном! - кричит в восторге Марья Александровна. - Ах, князь! неужели вы были знакомы с Бетховеном?

- Ну да... мы были с ним на дру-жес-кой но-ге. И вечно у него нос в табаке. Такой смешной!

упоминает И. Канта, размышляя о том, почему европейцы не могут русских «своими признать» [31. Т. 27. С. 35]. Автор подчеркивает, что «[о]ни, например, охотно сознаются, что русская наука может выставить уже несколько замечательных деятелей, представить несколько хороших работ, даже послуживших уже их европейской науке в пользу. Но ни за что, однако же, не поверит теперь Европа, что у нас в России могут родиться не одни только работники в науке (хотя бы и очень талантливые), а и гении, руководители человечества вроде Бэкона, Канта и Аристотеля. Этому они никогда не поверят, ибо в цивилизацию нашу не верят, а нашей грядущей идеи еще не знают» [31. Т. 27. С. 35]. 


\section{- Бетховен?}

- Ну да, Бетховен. Впрочем, может быть, это и не Бет-хо-вен, а какой-нибудь другой не-мец. Там очень много нем-цев... Впрочем, я, кажется, сби-ва-юсь» [31. Т. 2. С. 343].

Фигура Бетховена описывается пародийно, в духе хлестаковской лжи и не имеет ничего общего с реальностью, емко характеризуя князя Гаврилу. Во-первых, основным местожительства и творчества композитора был не родной Бонн, а Вена. Во-вторых, Бетховен никогда не курил. Скорее, это музыкальный символ Германии. Семикратное повторение в таком небольшом фрагменте текста имени немецкого композитора выполняет очень важную характеризующую роль. Князь стремится сделать себя причастным к выдающимся проявлениям европейской культуры, хотя бы в мордасовском салоне стать равновеликим творцам. Англия, Австрия, Германия, Франция быстро мелькают в речи престарелого князя К., причем литература, музыка, политика, философия упоминаются им в одном ряду, пародируя типичные темы «культурного» светского разговора. В этом заключается ирония Достоевского, что знакомство князя с ключевыми фигурами, творцами истории настолько поверхностно, нет глубокого знания и понимания, поэтому большой разницы между Бетховеным и, к примеру, Байроном и Наполеоном и поляком, ухарски танцующем краковяк на венском конгрессе, нет.

Ложь в духе Хлестакова продолжается совсем фантастической историей о том, как лакей Сидор сбежал от князя во Франкфруте: «Я, дейст-ви-тельно, в старину к одной масонской ложе за границей при-над-лежал и даже имел, в свою очередь, очень много великодушных идей. Я даже собирался тогда много сделать для сов-ре-менного прос-вещения и уж совсем было положил в Франкфурте моего Сидора, которого с собой за границу повез, на волю от-пус-тить. Но он, к удивлению моему, сам бежал от меня. Чрезвычайно странный был че-ло-век, потом вдруг встречаю его в Па-ри-же, франтом таким, в бакенах, идет по буль-вару с мамзелью. Поглядел на меня, кивнул го-ло-вой. И мамзель с ним такая бойкая, востроглазая, такая за-ман-чивая...» [31. Т. 2. С. 375-376].

В Германии действительно было очень развито масонское движение и ложи находились во многих городах, в том числе и во Франкфурте. К масонам принадлежал, в частности, и Бетховен. Гу- 
манистические идеи братского отношения комично преломляются в желании князя отпустить на волю своего слугу Сидора.

Таким образом, в существующей в сознании князя К. мифологической карте Германии имплицитно представлены топосы Кенисберга (Кант) и Бонна (Бетховен). Кроме того, гипотетически можно восстановить (скорее воображаемый, чем реальный) маршрут князя по Европе. Возможно, что в повести пародируются модные курорты Германии: Бад, Эмс, Висбаден, Баден-Баден, в которых практиковалось лечение гидропатией как универсальное средство от всех болезней. «Я, признаюсь, ничем не был болен; ну, пристали ко мне: “Лечись да лечись!” Я, из деликатности, и начал пить воду; думаю: и в самом деле легче сделается. Пил-пил, пил-пил, выпил целый водопад, и, знаете, эта гидропатия полезная вещь и ужасно много пользы мне принесла, так что если б я наконец не забо-лел, то уверяю вас, что был бы совершенно здоров...» [31. Т. 2. С. 315], - признается князь. Для создания юмористического эффекта используется гипербола («выпил целый водопад»), восходящая градация, а также прием обманутого ожидания: новейший способ лечения провоцирует болезнь.

В повести «Дядюшкин сон» травестийно обыгрывается увлечение наукой: «один немецкий ученый, нарочно приезжавший из Карльсруэ исследовать особенный род червячка с рожками, который водится в нашей губернии, и написавший об этом червячке четыре тома in quarto [в одну четверть листа (лат.)], так был обворожен приемом и любезностию Марьи Александровны, что до сих пор ведет с ней почтительную и нравственную переписку из самого Карльсруэ» [31. Т. 2. С. 297].

Название города, из которого приезжает безымянный энтомолог, в повести дано в неверной фонетической оболочке, с мягким л Карльсруэ для усиления юмористического эффекта. Вероятнее всего, что г. Карлсруэ (Karlsruhe) - столица Великого герцогства Баденского с населением в середине XIX в. в 50 тысяч жителей возникает в произведении Достоевского как символ европейской научной мысли и культуры. Основанный в 1825 г. по приказу великого герцога Людвига I Политехникум (Polytechnische Schule) стал первым техническим высшим учебным заведением в Германии. Возможно, что Достоевский мог слышать об этом от горных офицеров Барнаула, многие из которых были немцами и / или проходили стажировки в 
Германии. Внук основателя Карл Фридрих и его супруга Каролина Луиза Гессен Дармштадтская провозгласили Карлсруэ «двором муз», открыли придворный театр и Ботанический сад. Карл Фридрих особенно покровительствовал школам и университетам, его имя носит Гейдельбергский университет. Каролина Луиза была известна как коллекционер искусств, меценат и ботаник. В гостях при дворе бывали М.А. Вольтер, К.В. Глюк и И.В. Гете.

Возможно, что Достоевский также обыгрывает историю возникновения города и его названия. Согласно легенде, маркграф Карл III Вильгельм Дурлахский уснул в лесу во время охоты. Ему приснился прекрасный город-солнце, в центре которого стоял его замок. Он воплотил сон в жизнь в 1715 г., построив целый город, и перенес в него свою резиденцию. Karlsruhe буквально означает Карлова тишина, покой, отдых. Т.е., с одной стороны, это город, связанный с чудесным сном о будущем, а, с другой, - со смертью, могилой. Это еще и Карлов покой, место, где упокоено тело основателя. В центре города расположена каменная усыпальница, возведенная в 1823 г. великим герцогом Людвигом I Баденским. Она является символом города. Допускаем, что Достоевского заинтересовала перверсия смысла названия Карлсруэ: сон - смерть, созвучная главным событиям повести (чудесный сон, обернувшийся внезапной смертью дядюшки).

Кроме того, в пародийном образе биолога-немца из Карлсруэ содержится аллюзия на барнаульскую могилу энтомолога и врача Фридриха Августа Геблера, предки которого принадлежали к знатному старинному роду и занимали высокие должности при прусском и австрийском дворах.

Наконец, Карлсруэ в повести «Дядюшкин сон» включается в общую негативно-сатирическую обрисовку Германии в целом. Ироническое отношение к городу и Германии вызвано критикой писателя бездумной русской привязанности ко всему иностранному.

В сибирских произведениях Достоевского немецкие слова употребляются очень редко, т.к. автор плохо знал немецкий язык (в отличие, к примеру, от И.С. Тургенева, который обучался в Берлинском университете). Мы уже упоминали, что познания в немецком петербургского франта Мозглякова крайне скудны: он называет анекдот с перевернувшийся коляской князя премилой историей. Есть еще одно немецкое выражение, которое используется Достоевским в 
русской огласовке в ситуации, когда он подслушал разговор Москалевой с Зиной о необходимости выхода замуж за князя:

«- Что с вами, mon ami? - сказала она, подходя к нему и дружески протягивая ему свою руку.

- Как: monami! - вскричал он в бешенстве, - после того, что вы натворили, да еще: топаті. Морген-фри, милостивая государыня! И вы думаете, что обманете меня еще раз?

- Мне жаль, мне очень жаль, что вижу вас в таком странном состоянии духа, Павел Александрович. Какие выражения! вы даже не удерживаете слов ваших перед дамой.

- Перед дамой! Вы... вы все, что хотите, а не дама! - вскричал Мозгляков. Не знаю, что именно хотелось ему выразить своим восклицанием, но, вероятно, что-нибудь очень громовое» [31. Т. 2. С. 349].

Если Марья Александровна сохраняет наружное спокойствие и, как ни в чем не бывало, называет Павла Александровича «mon ami» (фp. мой друг), то Мозгляков почти в бешенстве, о чем свидетельствует мешанина русского, французского и немецкого в его речи. Принципиально важен контраст благозвучного, плавного и изящного французского с грубоватым, отрывистым произношением в немецком.

Выражение морген-фри в русской фонетической оболочке и через дефис (что свидетельствует о большей степени ассимиляции) используется дважды в следующем романе «Село Степанчиково и его обитатели» в устах степного помещика Бахчеева для характеризации героя.

«- Ну, так и есть! - вскричал господин Бахчеев, дав полную волю своему негодованию. - Я, батюшка, еще прежде, чем вы рот растворили, догадался, что вы философии обучались! Меня не надуешь! морген-фри! За три версты чутьем услышу философа! Поцелуйтесь вы с вашим Фомой Фомичом! Особенного человека нашел! тьфу! прокисай все на свете! Я было думал, что вы тоже благонамеренный человек, а вы... Подавай! - закричал он кучеру, уж влезавшему на козла исправленного экипажа. - Домой!» [31. Т. 3. С. 30].

В романе вновь пародируется классическое образование, включающее философию как неприменимую к практической жизни область. Акцентируем тот факт, что это выражение употреблено Бахчеевым еще раз, когда он рассказывает о заграничной игрушке для Илюши: «Завтра Ильи-пророка (господин Бахчеев перекрестился): Илюша, 
сынок-то дядюшкин, именинник. Я было думал и день у них провести, и пообедать там, и игрушку столичную выписал: немец на пружинах у своей невесты ручку целует, а та слезу платком вытирает - превосходная вещь! (теперь уж не подарю, морген-фри! Вон у меня в коляске лежит, и нос у немца отбит; назад везу)» [31. Т. 3. С. 27].

Обратим внимание, что комментаторы ППС дают неверное толкование этому немецкому выражению как morgen früh - ранним утром [31. Т. 3. С. 509]. Поскольку все существительные немецкого языка пишутся с заглавной буквы, то это выражение писалось бы в немецкой транскрипции как Morgen früh. Правильнее интерпретировать это выражение как восходящее к немецкому morgen früh - завтра утром. Из контекста повести и романа понятно, что присказка Мозглякова и Бахчеева функционирует в языке писателя как пословичное выражение и означает «нет», «не верю», «не сделаю», «меня не надуешь». М. Гиголошвили сравнивает значение указанного выражения с аналогичными разговорным в русском языке «черта с два», «жди у моря погоды» или с современным «разбежался» [42]. Добавим, что Достоевский мог обыграть разницу русского и немецкого менталитетов: когда немцы говорят «завтра утром», они действительно делают завтра утром. А если русские говорят «завтра», это может быть послезавтра, через месяц или даже никогда. И, следовательно, писатель использует вместо немецкого früh английскую фонетическую вокализацию free, что значит свободный (к примеру, free time -свободное время). Так у Достоевского получается языковая игра, выражение приобретает смысл «никогда не делать» (ср. в современном разговорном русском языке есть выражение «кормить завтраками» в значение многократно обещать сделать завтра, но так и не сделать обещанного). Также возможно, что автор смешивает в пределах фразы разные языки, чтобы показать волнение, эмоциональное состояние персонажа. М. Гиголошвили связывает переход немецкого «ӥ» в русское «и» при транслитерации с влиянием восточно-прусского диалекта, «который использовался и прибалтийскими немцами, основными «поставщиками» немецкого языка в России (среди колонистов, прибывающих через западно-южные границы России, был распространен швабский диалект). Сходное явление находим в «Скверном анекдоте», где слово «Frshstьck» дано Достоевским в том же восточно-прусском диалекте - «фрыштык» [42]. 
Тонкая ирония Достоевского заключена в том, что употребление разными персонажами в двух сибирских произведениях одного немецкого выражения в пословичном значении словно уравнивает степень владения немецким столичного франта Мозглякова и сельского помещика Степана Бахчеева.

Подробнее остановимся на семантике механической игрушки, купленной Бахчеевым в качестве подарка на день рождения Илюши. С одной стороны, диковинная игрушка немецкого производства олицетворяет достижения науки Германии, это символ надежности и качества. Но парадокс заключается в том, что чудесная вещь не выдерживает российских дорог - игрушечный немец теряет нос, вследствие чего дорогая игрушка уже непригодна для подарка. Казалось бы, эпизод исчерпан. Однако игрушка возвращается в финале романа, создавая кольцевую композицию и приобретая символическое значение. О «превосходной вещи» [31. Т. 3. С. 152] вспоминает Бахчеев в эпизоде благословения на брак полковника Ростанева и Настеньки.

«- А нос-то немцу ведь подклеили! - шепнул он мне конфиденциально, радостно смотря мне в глаза.

- Какой нос? какому немцу? - спросил я в удивлении.

- А вот выписному-то, что ручку-то у своей немки целует, а та слезу платком вытирает. Евдоким у меня починил вчера еще; а давеча, как воротились с погони, я и послал верхового... Скоро привезут. Превосходная вещь!» [31. Т. 3. С. 152].

Мы узнаем, что игрушку починил русский крепостной Евдоким. Бахчеев посылает за ней верхового домой: заграничная игрушка в виде влюбленной немецкой четы становится подарком на свадьбу. Сексуальный символизм игрушки с оторванным носом оказывается удивительно пророческим: любовь героев имеет духовносентиментальный характер: «Детей им бог не дал; они очень горюют об этом, но роптать не смеют. <..> дядя и Настя живут одни и не могут надышаться друг на друга» [31. Т. 3. С. 166].

Кроме того, в негативно-обобщенном виде Германия как страна чуждой европейской культуры оценивается крестьянином Григорием, уже пострадавшего от «просвещения» Фомы в виде французского языка. Говоря об утрате Видоплясовым патриотизма и нацио- 
нальной самобытности, он предлагает решить вопрос по-русски, радикально, с помощью физического насилия:

«- Да я б его, Видоплясова, - ввязался Григорий, который до сих пор чинно и строго наблюдал разговор, - да я б его, Видоплясова, из-под розог не выпустил. Нарвись-ко он на меня, я бы дурь-то немецкую вышиб! задал бы столько, что в два-ста не складешь.

- Молчать! - крикнул барин, - держи язык за зубами; не с тобой говорят!» [31. Т. 3. С. 26]. В этой реплике проявляется сатирическое снижение Германии как символа европейской культуры, моды и просвещения, которое не соответствует русскому менталитету и традициям. И здесь уже речь идет не о немецком как германском, а о немецком как любом чужом, иноязычном, пугающем, грозящем утратой национальной идентичности.

Видоплясов в романе представлен как шаржированный образ, воплощающий бездушное следование европейским течениям в «редакции» Фомы Фомича, а сам Опискин пытается учить крестьян французскому языку, хотя его собственные знания об этом предмете крайне ограничены. Об этом мы можем сделать вывод исходя из его странной и бессмысленной речи против ученого племянника Сережи:

«-Ученый! - завопил Фома, - так это он-то ученый? Либертеэгалите-фратерните! Журналь де деба! Нет, брат, врешь! в Саксонии не была! Здесь не Петербург, не надуешь! Да плевать мне на твой де деба! У тебя де деба, а по-нашему выходит: «Нет, брат, слаба!» Ученый! Да ты сколько знаешь, я всемерно столько забыл! вот какой ты ученый!» [31. Т. 3. С. 76].

В речи Фомы хаотично смешиваются с русскими словами девизы французской революции liberte, egalite, fraternite, название политической газеты «Journal des Debats», которое рифмуется с Саксонией восточной частью Германии. Это позволяет делать выводы, что не только знание французского, но и географические сведения героя поверхностны, не отличаются глубиной и системным характером.

В сибирских произведениях персонажи-немцы представлены эпизодически и слегка обозначены. «Так, например, в повести «Дядюшкин сон» среди желающих посетить Марию Александровну Москалеву по поводу якобы обсуждения театральных дел упоминается «...некая Луиза Карловна, которая “хотела быть”» [31. Т. 2. С. 369]. «Имя "Луиза ", усиленное отчеством "Карловна" - тут не 
может быть сомнений по поводу немецкого происхождения почтенной дамы», - считает Гиголашвили [42].

В романе «Село Степанчиково и его обитатели» в эпилоге упоминается безымянный управляющий-немец, который занимается воровством. «Говоря о судьбе Мизинчикова, автор замечает, что Ростанев рекомендовал его одному богатому графу, и тот “предложил ему место управляющего в своих поместьях, прогнав своего прежнего управителя немца, который, несмотря на прославленную немецкую честность, обчищал графа как липку"» [31. Т. 3. С. 167; 42]. Похожий персонаж возникает «в романе «Униженные и оскорбленные» с некоторым усилением темы и добавлением обстоятельств и подробностей» [42]. Князь Валковский «...прогнал своего управляющего, одного блудного немца, человека амбициозного, агронома, одаренного почтенной сединой, очками и горбатым носом, но, при всех преимуществах, кравшего без стыда и цензуры и, сверх того, замучившего нескольких мужиков. Иван Карлович был наконец пойман и уличен на деле, очень обиделся, много говорил про немецкую честность; но, несмотря на все это, был прогнан и даже с некоторым бесславием [31. Т. 3. С. 19]. По замечанию Гиголошвили, «[в] “Селе Степанчикове...” вор-управитель анонимен и лишен внешних примет, в "Униженных и оскорбленных" - уже назван (Иван Карлович) и бегло очерчен. Ироническое причастие “прославленная немецкая честность" во втором случае динамизируется с помощью наречия и глагола: “много говорил о немецкой честности”. Оба раза подчеркнуто, что управитель был прогнан» [42].

На наш взгляд, в этом эпизоде сатирически обыгрывается процесс обрусения немцев, когда их хозяйственность, меркантильность поставлены на службу собственного обогащения. Однако такие проявления имеют скорее индивидуальный, нежели национальный характер. Достоевский справедлив, когда тут же добавляет, что «Мизинчиков тоже пристроился» [31. Т. 3. С. 168]. Бросив надежды на обогащение с помощью выгодной женитьбы, он по рекомендации Ростанева становится управляющим. За пять лет ему удается нажить состояние для покупки «превосходнейшего имения, во сто душ», заложив которые через год он покупает еще шестьдесят. «Теперь он сам помещик, и хозяйство у него бесподобное» [31. Т. 3. С. 168]. Тем 
самым разница между действиями управляющего-немца и Мизинчикова заключается лишь в масштабах «практической сметки».

Итак, «немецкий мир» в художественном метатексте Достоевского подвергается мифопоэтической обработке. Писатель не только наследует литературную традицию сатирической обрисовки немецких артефактов и знаков культуры, но и углубляет ее. Комические художественные образы строятся на парадоксе, оксюмороне (борода размером с немецкое государство, Тирентий - Кант - индюк, от лечения гидропатией князь заболел и т.д.). Образ Германии создается стереоскопически, через обозначение знаковых культурных символов страны и личностей, представляющих вершины немецкой культуры (Кант, Бетховен, Шиллер, Гете). Обозначены важные топосы: Карлсруэ - город-солнце, основанный маркграфом Карлом III Вильгельмом; Франкфурт - хранилище государственной казны. Имплицитно обозначены водные курорты Бад, Эмс, Висбаден и БаденБаден. Символом достижений науки и техники Германии является механическая игрушка в виде влюбленной пары, демонстрирующей нормативно вежливое отношение джентльмена и его дамы.

В сибирских произведениях Достоевского нет ярких образов героев-немцев, это второстепенные эпизодические персонажи. Как правило, они безымянны (ученый-энтомолог, управляющий), либо имеют типичные имена - Луиза Карловна. Важно уточнить, что одной из причин создания Достоевским порой сатирических, доходящих до шаржа художественных образов являлось не выражение негативного отношения к Германии как таковой, сколько следствие недостаточного владения автором немецким языком в отличие от французского и английского. Язык Германии казался трудным и неблагозвучным писателю, поэтому немецкие выражения чаще даны в русской огласовке, а в зрелом творчестве немцы коверкают русские слова. Так проявляется автоирония Достоевского.

В итоге создается емкий, многогранный образ Германии. Средствами комического, путем гиперболизации, акцентирования, антитезы Достоевскому удается поставить серьезные вопросы чистоты русского языка, престижа и качества европейского образования, целесообразности культурной трансплантации, сохранения национальной идентичности. 


\section{Литература}

1. Долинин А.С. Достоевский и другие: Статьи и исследования о русской классической литературе. Л.: Художественная литература, 1989. $479 \mathrm{c}$.

2. Белов С.В. Федор Михайлович Достоевский: книга для учителя. М.: Просвещение, 1990. $206 \mathrm{c}$.

3. Hielscher $K$. Dostojewski in Deutschland. Erste Auflage. Frankfurt am Main und Leipzig: Insel Verlag, 1999. $290 \mathrm{~s}$.

4. Вильмонт Н.Н. Достоевский и Шиллер: Заметки русского германиста. М.: Советский писатель, 1984.279 с.

5. Данилевский Р.Ю. Фридрих Шиллер и Россия. СПб.: Издательство Пушкинского дома, 2013. 656 с.

6. Humiston Kim R. The Influence of Shiller's concept of aesthetics on Dostoevsky's major Fiction. The Florida State Universaty, 1987. 263 p.

7. Schulz C. Aspekte der Schiller'schen Kunsttheorie im literarischen Konzept von Dostojewski. München: Verlag Otto Sagner, 1992. $270 \mathrm{~s}$.

8. Евлампиев И.И. Философия человека в творчестве Ф. Достоевского (от ранних произведений к «Братьям Карамазовым»). СПб.: Изд-во Русской христианской гуманитарной академии, 2012. $585 \mathrm{c}$.

9. Комарович В. Достоевский и Гейне // Современный мир. 1916. № 10. C. 102-103.

10. Щенников Г.К. Иван Карамазов - русский Фауст // Достоевский в конце ХХ века. М.: Классика Плюс, 1996. С. 298-329.

11. Серман И.З. Достоевский и Гёте // Достоевский: Исследования и материалы. СПб.: Наука, 1997. Т. 14. С. 46-57.

12. Ковач А. Иван Карамазов: Фауст или Мефистофель // Достоевский: Исследования и материалы. СПб.: Наука, 1997. Т. 14. С. 153-163.

13. Жилякова Э.М. «Страдания юного Вертера» Гёте в контексте творчества Ф.М. Достоевского // Проблемы метода и жанра. Томск: Изд-во Том. ун-та, 1997. Вып. 19. С. 84-97.

14. Голосовкер Я.Э. Достоевский и Кант. Размышления читателя над романом Достоевского «Братья Карамазовы» и трактатом Канта «Критика чистого разума». М.: Изд-во АН СССР, 1963. $102 \mathrm{c.}$

15. Осмоловский О. Этическая философия Достоевского и Канта // Достоевский и мировая культура. 1999. № 12. С. 216-230.

16. Белопольский В.Н. Ф.М. Достоевский и философская мысль его эпохи: Концепция человека. Ростов н/Д.: Изд-во Ростов. ун-та, 1987. 206 с.

17. Дудкин В.В. Достоевский - Ницше: Проблема человека. Петрозаводск: Изд-во КГПИ, 1994. 153 с.

18. Дудкин В.В., Азадовский К.М. Достоевский в Германии (1846-1921): Новые материалы и исследования // Литературное наследство. М.: Наука, 1973. T. 86. C. $659-740$. 
19. Богданова О.А. «Братья Карамазовы» в Германии: В.Л. Комарович о последнем романе Ф.М. Достоевского // Русский язык за рубежом. 2012. № 4 (233). C. $72-77$.

20. Gerigk H.-J. Dostojewskijs Wirkung im deutschen Sprachraum (Fragmente eines Überblicks vom Fin de siècle bis heute) // Deutschland und Russland: Aspekte kultureller und wissenschaftlicher Beziehungen im 19. und frühen 20. Jahrhundert / Herausgeben von Dittmar Dahlmann, Wilfried Potthoff. Wiesbaden: Herrasowitz Verlag, 2004. S. 95-126.

21. Gerigk H.-J. Dostojewskij, der «vertrackte Russe». Die Geschichte seiner Wirkung im deutschen Sprachraum vom Fin de siècle bis heute. Tübingen: Attempto Verlag, 2000. $93 \mathrm{~s}$.

22. Dostojewskij und Europa / ed. Gudrun Goes. München Berlin: Verlag Otto Sagner, 2010. $192 \mathrm{~s}$.

23. Оболенская С.В. Германия и немцы глазами русских (XIX в.). М.: РАН. Ин-т всеобщ. истории, 2000. 209 с.

24. Криницын А.Б. Достоевский в Германии // Достоевский и XX век: В 2 т. М.: ИМЛИ РАН, 2007. Т. 2. С. 178-249.

25. Константинова Н.В. Немцы и немецкое в ранних произведениях Ф.М. Достоевского (на материале повести «Двойник») // Сибирский филологический журнал. 2014. № 4. С. 126-133.

26. Буткова Н.В. Образ Германии и образы немцев в творчестве И.С. Тургенева и Ф.М. Достоевского: дис. ... канд. филол. наук. Волгоград, 2001. 252 с.

27. Кидэра Р. Образ немцев в творчестве Достоевского // Труды Ростовского государственного университета путей сообщения. 2016. № 1 (34). С. 25-40.

28. Алексеев П.В. Биллиет Э. Образ Германии в «Дневнике писателя» Ф. Достоевского // Имагология и компаративистика. 2018. № 9. С. 67-79.

29. Владимириев В.П. Немецкая тема в «петербургской поэме» Ф.М. Достоевского «Двойник» // Три века русской литературы. Москва; Иркутск: Изд-во ИГПУ, 2004. Вып. 9. С. 176-182.

30. Чаппл Р. Материалы для «Словаря языка Достоевского» (реалии культуры, истории и быта Германии) //Достоевский: Исследования и материалы. СПб.: Наука, 1992. Т. 10. С. 242-254.

31. Достоевский Ф.М. Полное собрание сочинений: В 30 т. Л.: Наука, 19721990.

32. Пушкин А.С. Полное собрание сочинений: В 16 т. Л.: Изд-во АН СССР, 1937. T. $1.531 \mathrm{c}$.

33. Кант И. Религия в пределах только разума // Кант И. Трактаты и письма. М.: Наука, 1980. С. 78-278.

34. Калинников Л.А. «Житейские воззрения кота Мурра...» в зеркале житейских и метафизических воззрений Э.Т.А. Гофмана. Часть I. а // Кантовский сборник. 2012. № 2 (40). С. 30-47. 
35. Калинников Л.А. «Житейские воззрения кота Мурра...» в зеркале житейских и метафизических воззрений Э.Т.А. Гофмана. Часть 2. б // Кантовский сборник. 2012. № 3 (41). С. 35-48.

36. Калинников Л.А. «Житейские воззрения кота Мурра...» в зеркале житейских и метафизических воззрений Э.Т.А. Гофмана. Часть 3. в // Кантовский сборник. 2012. № 4 (42). С. 59-69.

37. Филиппов М.М. Иммануил Кант. Его жизнь и философская деятельность: биографический очерк. URL: https://7lafa.com/book.php?id=60420\&page=7

38. Историческая кулинария. Иммануил Кант. URL: https://paraboz.livejournal.com/142780.html

39. Даль В.И. Толковый словарь живого великорусского языка. СПб.; М.: Тип. М.О. Вольфа, 1881. Т. 2. 814 с.

40. Странные привычки Иммануила Канта. URL: https://zen.yandex.ru/media/id/5af71e6ac3321b2347a22fb3/strannye-privychki-immanuila-kanta-5afdc133a 936f442b08bae87

41. Пища для ума. Иммануил Кант (1724-1804). URL: https://psiholog.mirtesen.ru/blog/43259853921/Pischa-dlya-uma.-Immanuil-Kant-(1724-1804)?nr=1

42. Гиголашвили М. Борьба с европейщиной в «Сибирских повестях» Достоевского // Топос: сетевой журнал. 2012. URL: http://www.topos.ru/article/ bibliotechka-egoista/borba-s-evropeishchinoi-v-sibirskikh-povestyakh-dostoevskogo

\section{THE GERMANY'S IMAGE IN F.M. DOSTOEVSKY'S SIBERIAN WORKS}

Imagologiya $i$ komparativistika - Imagology and Comparative Studies, 2019, 12, pp. 113-141. DOI: 10.17223/24099554/12/6

Elena Yu. Safronova, Altai State University (Barnaul, Russian Federation). E-mail: esafr@mail.ru

Keywords: Dostoevsky, Germany, Siberia, topos, image, German, Uncle's Dream, The Village of Stepanchikovo and Its Inhabitants, poetics, comic.

Dostoevsky's Siberian works present a vivid, multidimensional image of Germany, created by topographic contrast as an attempt to reflect on national identity. If Siberia is the quintessence of Russia, then Germany is a symbol and centre of European civilization. On the one hand, Dostoevsky admires European culture (literature, philosophy, education), while on the other hand, the comic genre implies the reduction and parody of negative features of reality. The fruits of a cultural dialogue down to the extreme mindless passion for Germany are depicted in the humorous mode. The analysis of the writer's Siberian works demonstrates the following tendency: the lower the character's education, the worse his attitude to German (Gregory). On the contrary, people of culture show a different attitude towards Germany: respect and admiration, often leading to a loss of patriotism (Vidoplyasov, Opiskin, Prince K.). The "German world" in Dostoevsky's artistic metatext undergoes mythopoetic processing. The writer not only inherits the literary tradition of satirical depiction of German artefacts and cultural signs, but makes it more profound. The comic art images are built on a para- 
dox, oxymoron (a beard the size of a German state, Trentius-Kant-turkey, the prince falls ill after hydropathy, etc.). The image of Germany is created stereoscopically, through iconic cultural artefacts - symbols of the country and personalities representing the heights of German culture (Kant, Beethoven, Schiller, Goethe). The writer indentifies the most important topoi: Karlsruhe - the city of the sun founded by Margrave Charles III Wilhelm; Frankfurt - the repository of the state treasury. The water resorts of Bad, Ems, Wiesbaden and Baden-Baden are represented implicitly. The symbol of German technological progress is a mechanical toy of a couple in love, demonstrating the conventional attitude of a gentleman to his lady. There are no vivid images of German characters: they are minor episodic characters. As a rule, they are nameless (entomologist, manager), or have typical names (Louise Karlovna). It should be clarified that one of the reasons for creating satirical, cartoon-like images was not Dostoevsky's negative attitude towards Germany as such, but rather his insufficient knowledge of the German language, which seemed to him difficult and discordant; therefore, in Siberian works, German expressions are more often given in Russian vocalisation. Using comic means of aesthetics, hyperbolisation, emphasis, and antithesis, Dostoevsky succeeds in raising serious questions about the purity of the Russian language, prestige and quality of European education, feasibility of cultural transplantation, and preservation of national identity.

\section{References}

1. Dolinin, A.S. (1989) Dostoevskiy i drugie: Stat'i i issledovaniya o russkoy klassicheskoy literature [Dostoevsky and others: Articles and studies on Russian classical literature]. Leningrad: Khudozhestvennaya literatura.

2. Belov, S.V. (1990) Fedor Mikhaylovich Dostoevskiy [Fyodor Mikhailovich Dostoevsky]. Moscow: Prosveshchenie.

3. Hielscher, K. (1999) Dostojewski in Deutschland. Erste Auflage. Frankfurt am Main; Leipzig: Insel Verlag.

4. Vilmont, N.N. (1984) Dostoevskiy i Shiller: Zametki russkogo germanista [Dostoevsky and Schiller: Notes of the Russian Germanist]. Moscow: Sovetskiy pisatel'.

5. Danilevsky, R.Yu. (2013) Fridrikh Shiller i Rossiya [Friedrich Schiller and Russia]. St. Petersburg: The Pushkin House.

6. Humiston, K.R.(1987) The Influence of Shiller's concept of aesthetics on Dostoevsky's major fiction. Florida State University.

7. Schulz, C. (1992) Aspekte der Schiller'schen Kunsttheorie im literarischen Konzept von Dostojewski. München: Verlag Otto Sagner.

8. Evlampiev, I.I. (2012) Filosofiya cheloveka v tvorchestve F. Dostoevskogo (ot rannikh proizvedeniy $k$ "Brat'yam Karamazovym") [The philosophy of man in the works of F. Dostoevsky (from early works to "The Brothers Karamazov")]. St. Petersburg: Russian Christian Academy for the Humanities. 
9. Komarovich, V. (1916) Dostoevskiy i Geyne [Dostoevsky and Heine]. Sovremennyy mir. 10. pp. 102-103.

10. Shchennikov, G.K. (1996) Ivan Karamazov - russkiy Faust [Ivan Karamazov - Russian Faust]. In: Stepanyan, K. (ed.) Dostoevskiy v kontse XX veka [Dostoevsky in the late 20th century]. Moscow: Klassika Plyus. pp. 298-329.

11. Serman, I.Z. (1997) Dostoevskiy i Gete [Dostoevsky and Goethe]. In: Budanova, N.F. \& Arhipova, A.V. (eds) Dostoevskiy: Materialy i issledovania [Dostoevsky: Materials and Research]. Vol. 14. St. Petersburg: Nauka. pp. 46-57.

12. Kovach, A. (1997) Ivan Karamazov: Faust ili Mefistofel' [Ivan Karamazov: Faust or Mephistopheles]. In: Budanova, N.F. \& Arhipova, A.V. (eds) Dostoevskiy: Materialy i issledovania [Dostoevsky: Materials and Research]. Vol. 14. St. Petersburg: Nauka. pp. 153-163.

13. Zhilyakova, E.M. (1997) "Stradaniya yunogo Vertera" Gete v kontekste tvorchestva F.M. Dostoevskogo [Goethe's "The Sorrows of Young Werther" in the context of F.M. Dostoevsky's creativity]. In: Kanunova, F.Z. (ed.) Problemy metoda $i$ zhanra [Problems of Method and Genre]. Tomsk: Tomsk State University. pp. 84-97.

14. Golosovker, Ya.E. (1963) Dostoevskiy i Kant. Razmyshleniya chitatelya nad romanom Dostoevskogo "Brat'ya Karamazovy" i traktatom Kanta "Kritika chistogo razu$m a$ " [Dostoevsky and Kant. The reader's thoughts on Dostoevsky's novel "The Brothers Karamazov" and Kant's treatise "Critique of Pure Reason"]. Moscow: USSR AS.

15. Osmolovsky, O. (1999) Eticheskaya filosofiya Dostoevskogo i Kanta [Ethical Philosophy of Dostoevsky and Kant]. Dostoevskiy i mirovaya kul'tura. 12. pp. 216-230.

16. Belopolsky, V.N. (1994) F.M. Dostoevskiy i filosofskaya mysl' ego epokhi: Kontseptsiya cheloveka [F.M. Dostoevsky and the philosophical thought of his era: The concept of man]. Rostov-on-Don: Rostov State University.

17. Dudkin, V.V. (1994) Dostoevskiy - Nitsshe: Problema cheloveka [Dostoevsky - Nietzsche: The Problem of Man]. Petrozavodsk: KSPI.

18. Dudkin, V.V. \& Azadovsky, K.M. (1973) Dostoevskiy v Germanii (18461921): Novye materialy i issledovaniya [Dostoevsky in Germany (1846-1921): New materials and research]. In: Shcherbina, V.N. (ed.) Literaturnoe nasledstvo [Literary Heritage]. Vol. 86. Moscow: Nauka. pp. 659-740.

19. Bogdanova, O.A. (2012) "Brat'ya Karamazovy" v Germanii: V.L. Komarovich o poslednem romane F.M. Dostoevskogo ["The Brothers Karamazov" in Germany: V.L. Komarovich about the last F.M. Dostoevsky's novel]. Russkiy yazyk za rubezhom - Russian Language Abroad. 4(233). pp. 72-77.

20. Gerigk, H.-J. (2004) Dostojewskijs Wirkung im deutschen Sprachraum (Fragmente eines Überblicks vom Fin de siècle bis heute). In: Dahlmann, D. \& Potthoff, W. (eds) Deutschland und Russland: Aspekte kultureller und wissenschaftlicher Beziehungen im 19. und frühen 20. Jahrhundert. Wiesbaden: Herrasowitz Verlag. pp. 95-126.

21. Gerigk, H.-J. (2000) Dostojewskij, der "vertrackte Russe”. Die Geschichte seiner Wir-kung im deutschen Sprachraum vom Fin de siècle bis heute. Tübingen: Attempto Verlag. 
22. Gudrun, G. (ed.) (2010) Dostojewskij und Europa. Munich; Berlin: Verlag Otto Sagner.

23. Obolenskaya, S.V. (2000) Germaniya i nemtsy glazami russkikh (XIX v.) [Germany and Germans Through the Eyes of Russians (the 20th century)]. Moscow: RAS.

24. Krinitsyn, A.B. (2007) Dostoevskiy v Germanii [Dostoevsky in Germany]. In: Kasatkina, T. et al. (eds) Dostoevskiy i XX vek: V 2 t [Dostoevsky and 20th century: In 2 vols]. Vol. 2. Moscow: IMLI RAS. pp. 178-249.

25. Konstantinova, N.V. (2014) Germans and German in the early works by F.M. Dostoyevsky (on the basis of the story "The Double"). Sibirskiy filologicheskiy zhurnal - Siberian Journal of Philology. 4. pp. 126-133. (In Russian).

26. Butkova, N.V. (2001) Obraz Germanii i obrazy nemtsev v tvorchestve I.S. Turgeneva i F.M. Dostoevskogo [The image of Germany and Germans in the works by I.S. Turgenev and F.M. Dostoevsky]. Philology Can. Diss. Volgograd.

27. Kidera, R. (2016) Obraz nemtsev v tvorchestve Dostoevskogo [The image of the Germans in the works by Dostoevsky]. Trudy Rostovskogo gosudarstvennogo universiteta putey soobshcheniya. 1(34). pp. 25-40.

28. Alekseev, P.V. \& Billiet, E. (2018) The image of Germany in "A Writer's Diary" by Fyodor Dostoevsky. Imagologiya i komparativistika - Imagology and Comparative Studies. 9. pp. 67-79. (In Russian). DOI: 10.17223/24099554/9/5

29. Vladimirtsev, V.P. (2004) Nemetskaya tema v "peterburgskoy poeme" F.M. Dostoevskogo "Dvoynik" [The German theme in the "Petersburg poem" by F.M. Dostoevsky “The Double"]. In: Solntseva, N.M. (ed.) Tri veka russkoy literatury [Three Centuries of Russian Literature]. Vol. 9. Moscow; Irkutsk: Irkutsk State University. pp. 176-182.

30. Chapple, R. (1992) Materialy dlya "Slovarya yazyka Dostoevskogo" (realii kul'tury, istorii i byta Germanii) [Materials for the "Dictionary of Dostoevsky's language" (realities of German culture, history, and life)]. In: Fridlender, G.M. (ed.) Dostoevskiy: materialy $i$ issledovaniya [Dostoevsky: Materials and Research]. Vol. 10. St. Petersburg: Nauka. pp. 242-254.

31. Dostoevsky, F.M. (1972-1990) Polnoe sobranie sochineniy: v $30 t$ [Complete Works: In 30 vols]. Leningrad: Nauka.

32. Pushkin, A.S. (1937) Polnoe sobranie sochineniy: $V 16 t$ [Complete Works: In 16 vols]. Vol. 1. Leningrad: USSR AS.

33. Kant, I. (1980) Traktaty $i$ pis'ma [Treatises and Letters]. Translated from German. Moscow: Nauka. pp. 78-278.

34. Kalinnikov, L.A. (2012) "The Life and Opinions of Tomcat Murr..." in light of worldly and metaphysical views of Ernst Theodor Wilhelm Hoffmann. Part I. Kantovskiy sbornik - Kantian Journal. 2(40). pp. 30-47. (In Russian). DOI: 10.5922/0207-6918-2012-2-3

35. Kalinnikov, L.A. (2012) "The Life and Opinions of Tomcat Murr..." in light of worldly and metaphysical views of Ernst Theodor Wilhelm Hoffmann. Part 2. Kantovskiy sbornik - Kantian journal. 3(41). p. 35-48. (In Russian). DOI: 10.5922/02076918-2012-3-3 
36. Kalinnikov, L.A. (2012) "The Life and Opinions of Tomcat Murr..." in light of worldly and metaphysical views of Ernst Theodor Wilhelm Hoffmann. Part 3. Kantovskiy sbornik - Kantian journal. 4(42). pp. 59-69. (In Russian). DOI: 10.5922/0207-6918-2012-4-7

37. Filippov, M.M. (n.d.) Immanuil Kant. Ego zhizn' i filosofskaya deyatel'nost': biograficheskiy ocherk [Immanuel Kant. His life and philosophical work: a biographical sketch]. [Online] Available from: https://7lafa.com/book.php?id=60420\&page=7

38. Anon. (2012) Istoricheskaya kulinariya. Immanuil Kant [Historic cooking. Immanuel Kant]. [Online] Available from: https://paraboz.livejournal.com/ 142780.html

39. Dal, V.I. (1881) Tolkovyy slovar' zhivogo velikorusskogo yazyka [Explanatory Dictionary of the Living Great Russian Language]. Vol. 2. St. Petersburg; Moscow: Tip. M.O Vol'fa.

40. Anon. (2018) Strannye privychki Immanuila Kanta [The strange habits of Immanuel Kant]. [Online] Available from: https://zen.yandex.ru/media/id/5af71e6ac 3321b2347a22fb3/strannye-privychki-immanuila-kanta-5afdc133a936f442b08bae87

41. Anon. (2016) Pishcha dlya uma. Immanuil Kant (1724-1804) [Food for brain. Immanuel Kant (1724-1804)]. [Online] Available from: https://psiholog.mirtesen.ru/ blog/43259853921/Pischa-dlya-uma.-Immanuil-Kant-(1724-1804)?nr=1

42. Gigolashvili, M. (2012) Bor'ba s evropeyshchinoy v "Sibirskikh povestyakh" Dostoevskogo [Fighting Europeanism in Dostoevsky's "Siberian Tales"]. [Online] Available from: http://www.topos.ru/article/bibliotechka-egoista/borba-sevropeishchinoi-v-sibirskikh-povestyakh-dostoevskogo 